\title{
Article
}

\section{Determination of the influence of specific building regulations in smart buildings}

\author{
Anglés, Susana, Ganah, Abdulkadir, Santos, Alfonso, Leube, \\ Francisco and Rincón, Oscar \\ Available at http://clok.uclan.ac.uk/11016/ \\ Anglés, Susana, Ganah, Abdulkadir ORCID: 0000-0002-9911-8505, Santos, \\ Alfonso, Leube, Francisco and Rincón, Óscar (2014) Determination of the \\ influence of specific building regulations in smart buildings. Intelligent \\ Buildings International, 6 (4). pp. 239-254. ISSN 1750-8975
}

It is advisable to refer to the publisher's version if you intend to cite from the work. http://dx.doi.org/10.1080/17508975.2014.944085

For more information about UCLan's research in this area go to http://www.uclan.ac.uk/researchgroups/ and search for <name of research Group>.

For information about Research generally at UCLan please go to http://www.uclan.ac.uk/research/

All outputs in CLoK are protected by Intellectual Property Rights law, including Copyright law. Copyright, IPR and Moral Rights for the works on this site are retained by the individual authors and/or other copyright owners. Terms and conditions for use of this material are defined in the policies page. 


\title{
Determination of the influence of specific building regulations in smart buildings
}

Final draft, published as:

Millán, S., Ganah, A., García, A., Jiménez, F.J. and Higuera, O. (2014), Determination of the influence of specific building regulations in smart buildings, Intelligent Buildings International, Vol. 6, No. 4, 239-254, http://dx.doi.org/10.1080/17508975.2014.944085

\section{Please cite the published version.}

\begin{abstract}
The automation of domestic services began to be implemented in buildings since the late nineteenth century, and today we are used to terms like 'intelligent buildings', 'digital home' or 'domotic buildings'. These concepts tell us about constructions which integrate new technologies in order to improve comfort, optimise energy consumption or enhance the security of users. In conjunction, building regulations have been updated to suit the needs of society and to regulate these new facilities in such structures. However, we are not always sure about how far, from the quantitative or qualitative point of view, legislation should regulate certain aspects of the building activity.

Consequently, content analysis is adopted in this research to determine the influence of building regulations in the implementation of new technologies in the construction process. This study includes the analysis of different European regulations, the collection and documentation of such guidelines that have been established and a study of the impact that all of these have had in the way we start thinking an architectural project.

The achievements of the research could be explained in terms of the regulatory requirements that must be taken into account in order to achieve a successful implementation of a home automation system, and the key finding has been the confirmation of how the design of smart buildings may be promoted through specific regulatory requirements while other factors, such as the global economic situation, do not seem to affect directly the rate of penetration of home automation in construction.

Keywords: Cultural Difference, Digital Homes, Building Automation Systems, Innovation and Intelligent Building.
\end{abstract}

\section{1 - Introduction}

Most people spend more time in their homes than in any other place. 'Home' ideally provides a comfortable and safe environment in which to relax, learn, communicate, socialise and entertain. Huge amounts of money and time are invested by people to transfer their homes into living spaces that meet their needs and desires. At the same time, improvements, innovations and advances in construction are under current development focusing on a variety of facets of the constructive process. However, not all advances and innovations involve the introduction into architecture of technologies which are not typical of it. Focusing on those technologies related to smart buildings implies to study technologies that entail new considerations in the design stage of such buildings, e.g. how a computer network is integrated in the constructed reality.

The concept of smart buildings was initially introduced for office buildings in the United States in the early 1980s in order to save energy and to increase productivity. Although no formal definition exists, smart buildings use electronics extensively and are highly related to telecommunication technologies. The concept was later applied to 
residences to provide occupants with more comfortable lives. 'Smart building' is a term commonly used to describe a residence that uses a centralised control to integrate the various home automation systems. Originally, 'domotic' technology was used to control environmental systems such as heating and lighting, but recently the use of domotic technology has been developed so that almost any electrical component within the house can be included in the system [1].

The benefits of designing a building as an intelligent one is well documented in terms of energy, environment, social life and even from the point of view of personal wellbeing [2] [3]. This evidence leads to the question of why the concept of intelligent building has not been adopted in a more generally way in the present era. Some authors believe that the technology used in smart buildings is still only affordable to sectors of the population with large amounts of disposable income [4]. However, there is little doubt that, in the near future, domotic technology will be more affordable to many income groups, with a possible increase in demand. Furthermore, it is possible to prove that the cost of automation systems will eventually be self-funding through the energy saving acquired with the installation, this can be added to the effort made by new technology companies to cheapen automation systems [5]. Apart from these considerations focused on supporting and promoting home automation, this research considers the possibility that legislation can be another tool to help spread the concept of intelligent buildings, which leads to the consideration that a better understanding of the influence of building regulations in smart buildings is needed.

When designing a building, the starting point should be to consider the relevant legislation to the specific project and to determine the essential requirements that must be met. Similarly, when an automated installation is designed, it is necessary to know what requirements these facilities must meet. It can be said, therefore, that the influence of regulations in a particular project is measured through the mandatory requirements applicable. And in relation to this issue, both independent and statistical sources often reveal that a particular regulatory requirement promotes the implementation of specific constructive solutions.

The aim of this research is, therefore, to determine the influence of specific building regulations on smart buildings. To describe how the study was developed, this article has been structured as follows: Firstly, the explanation of the methodology is presented. Secondly, the background related to smart buildings is explained and the variables needed for the research are listed. Then, the Spanish and British regulations are considered separately and an analysis of the Market Data is made. And finally, taking into account the results of the analysis done, the conclusions can be drawn and explained.

\section{2 - Methodology}

Since this research mainly handles recorded human communications, the methodology in this study is based in content analysis [6]. 'Content analysis' is a research tool focused on the actual content and internal features of verbal and nonverbal material, whatever the chosen media is. It has been documented that this is a very suitable method to be applied to studies to reveal international differences in communication content and policy documents [7,8], and it is a type of document analysis technique that facilitates the analysis of the documentation available from both a qualitative and quantitative point of view. 'Conceptual Analysis' $[9,10]$ is a variant of the 'Content Analysis' method also used during this research, in this case the strategy seeks for the repetitions of some concepts and terms in the documents to be analyzed.

To use this method, it is necessary to conduct complementary research about the terms 
related with smart buildings and the differences in terminology between countries. This complementary research shows that, not only does each geographical area prefer to use certain terms over others, it has also detected that the proposed definitions have slightly differences in meaning and that they place emphasis on different aspects of home automation (see Table 1).

\begin{tabular}{|c|c|c|c|c|c|}
\hline \multirow{2}{*}{$\begin{array}{l}\text { Geographic } \\
\text { Area }\end{array}$} & \multirow[b]{2}{*}{ USA } & \multicolumn{3}{|c|}{ European Continent } & \multirow[b]{2}{*}{ Asia } \\
\hline & & France & \begin{tabular}{|l|} 
UK \\
\end{tabular} & Others & \\
\hline $\begin{array}{l}\text { Representative } \\
\text { references }\end{array}$ & $\begin{array}{l}\text { (NAHB 1980) } \\
\text { (Gross 1998) }\end{array}$ & $\begin{array}{l}(\text { Humbert 1982) } \\
\text { (Larousse 1988) } \\
\text { (FIEE et al. 1988) } \\
\text { (Nouveau Dictionaire 1989) } \\
\text { (Dard 1990) }\end{array}$ & \begin{tabular}{|l|} 
(Derek, T. and J. Clements- \\
Croome 1997) \\
(Yang and Peng 2001) \\
(Wigginton and Harris \\
2002) \\
\\
\end{tabular} & $\begin{array}{l}\text { (Dootingh 1990, ESPRIT } \\
\text { PROJECT) } \\
\text { Instituto Cerdá. (1990) } \\
\text { Flórez de la Colina, M.A. } \\
\text { (2004) } \\
\text { Huidobro, J.M. and R.J. } \\
\text { Millán. (2004) }\end{array}$ & $\begin{array}{l}\text { (So, A.T.et al. 1999) } \\
\text { (Wong, J. et al. 2005) } \\
\text { (Yiu, C. and Y. Yau 2006) }\end{array}$ \\
\hline $\begin{array}{l}\text { Commonly used } \\
\text { expressions }\end{array}$ & $\begin{array}{l}\text { Intelligent Buildings } \\
\text { Smart } \\
\text { Buildings/Houses } \\
\text { Home Automation }\end{array}$ & Domotique (Domotics) & $\begin{array}{l}\text { Home Automation } \\
\text { Intelligent Buildings } \\
\text { Smart Buildings }\end{array}$ & $\begin{array}{l}\text { Home Systems } \\
\text { Domótica (Domotics) } \\
\text { Hogar Digital (Digital } \\
\text { Home) } \\
\text { Inteligencia Anbiental } \\
\text { (Intelligent Ambient) } \\
\text { Hogar Digital Conectado" } \\
\text { (connected digital home") }\end{array}$ & $\begin{array}{l}\text { Intelligent Building } \\
\text { Intelligent Home }\end{array}$ \\
\hline $\begin{array}{l}\text { Main concepts, } \\
\text { features and } \\
\text { functions }\end{array}$ & \begin{tabular}{|l} 
To employ sensors \\
and control systems to \\
monitor a dwelling \\
To provide a safer, \\
more comfortable, and \\
more economical \\
dwelling \\
It speaks about: \\
building structurc, \\
building systems, \\
building services and \\
building management.
\end{tabular} & $\begin{array}{l}\text { Use of hardware components, } \\
\text { connection to personal } \\
\text { computers } \\
\text { Integrates all security } \\
\text { automation, energy } \\
\text { management, communications, } \\
\text { etc } \\
\text { Application of computing to } \\
\text { housing } \\
\text { Set of services in the habitat } \\
\text { provided by the systems } \\
\text { Connected together and with } \\
\text { external communication } \\
\text { networks } \\
\text { Functions included: energy } \\
\text { conservation and management } \\
\text { of technology, information and } \\
\text { communication, control, } \\
\text { comfort and security } \\
\text { It is a social and technical } \\
\text { process }\end{array}$ & $\begin{array}{l}\text { Intelligence applied to the } \\
\text { building } \\
\text { System able to respond to } \\
\text { individual, organisational } \\
\text { and environmental } \\
\text { requirement and to cope } \\
\text { with changes } \\
\text { One of the main goals is to } \\
\text { achicve efficicent } \\
\text { mangement of resources } \\
\text { with minimum life-time } \\
\text { costs of hardware and } \\
\text { facilities }\end{array}$ & $\begin{array}{l}\text { Emphasis is on information } \\
\text { technology } \\
\text { Convergence of services: } \\
\text { entertainment, } \\
\text { communications and the } \\
\text { digital management of the } \\
\text { house } \\
\text { A structure of independent } \\
\text { networks } \\
\text { System that includes the } \\
\text { Internet connection } \\
\text { Emphasizes on centralized } \\
\text { control } \\
\text { Also emphasizes on the } \\
\text { elements that provide the } \\
\text { media access (wiring). }\end{array}$ & $\begin{array}{l}\text { Focused on user needs and } \\
\text { the requirements of the user } \\
\text { It should privide advanced } \\
\text { automatic control systems to } \\
\text { monitor services } \\
\text { It should have good } \\
\text { networking infraestructure } \\
\text { It should provide adequate } \\
\text { tele-communication facilities } \\
\text { Automatic functions: } \\
\text { communication automation, } \\
\text { office automation and } \\
\text { building management } \\
\text { automation } \\
\text { Rationalisation of building } \\
\text { administration to provide } \\
\text { more attentive administrative } \\
\text { services with lower cost } \\
\text { Enviromental friendly } \\
\text { Space utilisation and } \\
\text { flexibility } \\
\text { Image of high technology }\end{array}$ \\
\hline
\end{tabular}

Table 1: The use of terms related to smart buildings

Using this information and other expressions related to home automation, the presence of certain words, concepts, themes, phrases, characters, or sentences have been determined in the regulatory documents to find all the contents directly or indirectly related to smart buildings.

Focusing on the aim of the research, this analysis has been developed primarily in three distinct phases:

(i) The first phase consists of selecting and surveying those countries whose laws were going to be studied.

(ii) The second phase, more mechanical, consists of collecting all the policy documents of the selected countries; in this phase, each normative document was studied separately.

(iii) Finally, and once the influence of regulations studied was detected, a third phase 
was carried out to collect public data from independent entities that reflects the impact of such regulations on the housing market.

\section{Phase 1: Identification of variables and basic concepts: choice of countries to study}

In this first phase, all the existing definitions of smart building and home automation installation have been studied in order to formulate concepts and definitions which will guide the rest of the study. Ultimately, it was necessary to proceed to analyse and decide on the rules and countries subject to study. For this phase a previous study of the current regulations in Europe was required. The possibility of studying more than one state regulation was considered and, at the end, it was decided to study the regulation of two countries in order to establish simple comparisons between them. It was considered that the main requirement was that both regulatory standards should be different enough to assess the consequences of two different ways of regulating the building activity.

\section{Phase 2: Data collection and analysis of the applicable regulations in the countries under study}

This second phase was primarily analytical and mechanical. All the applicable regulations of the countries under study were compiled and then, one by one, each of the documents was analysed in detail to detect and isolate those aspects that directly or indirectly affect the design of smart buildings. The documentation necessary to carry out this phase of the research is relatively easy to find because they are all official documents issued by the respective governments in each country under study.

\section{Phase 3: Data collection and analysis of data on the evolution of the real estate market and on the introduction of new technologies in smart buildings}

The last phase of research and analysis was to collect and analyse social and public information regarding real estate market trends and developments in the implementation of home automation solutions in buildings. This information consists of official statistics and publications of independent entities and standards bodies. The analysis of this information allows the establishment of possible consequences of different methods of regulation.

After developing these three phases of study and documentation, the next step was to proceed to formulate the conclusions of the study. For this purpose, the influence of government regulations in both countries and the market data collected for each country have been compared. Comparisons have also been made with other specific European rules.

\section{3 - Background}

It is well known that there were no domotics in the first half of the twentieth century [11]. Up to then, authors talk only about isolated automation designed for domestic use where the concept of integration into buildings was not even considered. Our starting point is, therefore, with those first devices which were not very useful or the first automations of ancient Ethiopia [12]. In Vitruvio's ten books of architecture, descriptions of machines which were used in construction can be found, along with Villard de Honecourt's very famous attempt at a continuous engine [13]. But it's from the fifteenth century and Leonardo Da Vinci's illustrations that evidence of the first devices conceived to execute essentially human and domestic tasks can be found. Therefore, it can be argued that domotics is a process which derives from a sequence 
(mechanic-automatic-domotic), and it can also be asserted that the concept arises when human beings rid themselves of devices in order to directly automate the environment they are living in.

The best known authors, and the ones who have documented this discipline [14], set its origin in the 1970s when the first automation devices emerged using X-10 technology. Simultaneously, the first electrical appliances that appeared in the US were thought of as specifically for home usage [15], that was when the first devices installed to control temperature comfort in office buildings came about. At the end of the 1980s, together with the rise of PCs, the first organised wired systems which connected peripherals to terminals with a standard cable appeared, and then the expression 'smart buildings' began to be used [16]. In 1988 the Larousse Encyclopaedia was the first to propose a definition for the term 'domotics', but a final and commonly used definition has not been agreed since then. [17].

There are many views of the term 'smart buildings' or 'domotics' [18]. Terefore, prior to the development of the research and in order to develop the study properly, a definition of the concepts 'domotics' and 'integrated domotic installations' has been established to be used in this research henceforth.

For the purpose of this research, 'Domotics' is defined as the expandable group of services that integrate into the house to a greater or lesser extent, that are supplied by systems able to take shape in one or several internal networks, and that are capable of (at the same time) communicating with external networks from inside the house. These services implement functions related to energy saving, technical management of installations, data, communications, leisure, accessibility, assistance and comfort. They can be controlled from one or several points or management centres.

'Integrated domotic installation' is defined as an integrated installation in architecture where the main components perform a double function. The first is to offer a domotic service and the second one is to be a construction element inside the architectural project. That is, they replace or belong to conventional construction elements or they are constituent elements of the architectural composition [19].

\section{4 - European Law Enforcement}

Legislation should reflect the needs of society. Consequently, there are differences between the ways of developing (from a common structure) such legislation in each country of the European Union. How far legislation should regulate an aspect of building activity is, in itself, an issue that deserves detailed study. This is because in the same way that abundant regulation can guarantee the quality of a particular building system, it could also jeopardise, if it is too rigid, the technological evolution of the same construction system.

This study is part of a research project carried out in Spain regarding constructional constraints in the design of smart buildings [20]. For this reason, the Spanish regulations were the first to be studied. However, due to the influence of agreements reached within the European Union, the building regulations in each member country have been transformed to try to follow or to adapt to common guidelines. As a result, some legislation, such as the Spanish one, has experienced in just five years a dramatic transformation that is still in process [21]. Furthermore, legislation exists in other countries that has been developed in a very different way, either more extensively or because its specifications are detailed more intensively.

Because of these factors, it was decided to study the building legislation of a second country. The second country needed to be representative of Europe and, at the same time, different from the Spanish experience, in order to encourage effective comparison 
between different rules whilst still within the context of EU guidelines. After studying several countries, it was noted that Germany is a major representative of the European frameworks. However, the fact that Spanish legislation has been updated in recent years to catch up with European Directives, made the Spanish and German legislation too similar so an interesting comparison could not be achieved.

That is why it was worth looking for legislation that could be more independent and distinct in terms of a different vocation and philosophy and whose documentations were equally accessible. For this reason, it was finally decided to compare the case of Spain with the UK. This choice made possible to compare a legislation whose mission is focused on the objectives, such as the English one, with another based on specific requirements such as the Spanish one. To clarify the concept, it is said that legislation is focused on objectives when it states the level of the regulatory demands without describing a specific constructional solution to achieve those demands. On the other hand, a legislation focused on specific requirements does the opposite; it sets the specific constructional solutions in order to assure that the adequate level of regulatory demands will be achieved.

This work, therefore, focuses on Spanish and British legislation or, to be more precise, the British one is represented by the regulatory documents of England and Wales, considering these documents representative of the UK as a whole for its content unit. Both countries are members of the European Union and both are characterised by a strong personality that clearly differentiates one from the other. As it is going to be explained, there is no extensive legislation specifically dedicated to regulating the design of smart buildings in general. For that reason and for this study, the analysis of all applicable legislation in both countries has been made in order to detect regulatory requirements that may directly or indirectly affect the design of smart buildings. Thus, during the analysis the following distinctions have been made:

- "Regulatory requirements that directly affect the design of smart buildings"

- "Regulatory requirements that indirectly affect the design of smart buildings"

For example, if it be considered that one of the applications of smart buildings is energy efficiency then we could conclude that any legislation that has to do with the optimisation of energy efficiency could affect smart building design. To go into more detail; if what we have is legislation that regulates heat production machines in a building, what we have here is regulation that, for now, only indirectly affects the design of smart buildings. On the contrary, if we have legislation governing the way in which we automate, manage and control the switching on/off of lights, with an energy saving goal, then we are talking about legislation that directly affects the design of smart buildings.

In this study, the focus is not on how to regulate energy efficiency. The aim is to identify how far the rules regulate specific aspects of building automation and intelligent management in general for any application, whether energy efficiency, accessibility, comfort, security, etc., and then to determine if there exists an influence of this regulation in the design of smart buildings.

There are standards bodies that develop automation systems standards, but presently they do not affect the construction of architectural reality. For this reason these standards are not included in this paper, nor is the study of specific rules of construction products, due to the zero impact they have on architectural design.

\section{5 - Spanish Regulation}

In Spain, there is currently no legislation specifically created to regulate facilities for home automation. However, there are two state/national regulations that include an 
epigraph dedicated to the subject of home automation. Therefore, it can be said that these regulations contain requirements which directly affect smart building design. On the one hand, there is the 'Reglamento de la Infraestructura común de Telecomunicaciones (RICT)' [22] which regulates telecommunications infrastructure in dwellings. On the other hand, there is the 'Reglamento Electrotécnico de Baja Tensión (REBT)' [23] where theoretically, all technical requirements and the necessary guarantees that the automated systems must meet can be found.

The objective of the REBT is to establish the technical conditions and the guarantees to be met in electrical installations connected to a power supply in low voltage limits. The concluding technical instruction (or ITCs) inside the REBT is the 'ITC-BT-51', which is responsible for describing regulatory requirements in the field of domotics. The European standard of reference is 'UNE-EN 50090-2-2'. This standard regulates the general technical requirements of "Home and Building Electronic Systems".

The ITC-BT-51 comprises only three pages of rules. Despite that, it is the first regulation of the infrastructure needed for a home automation installation. The new terminology introduced by this instruction is reduced to six terms, whereas the document ITC-BT-51 classifies three types of different automation systems and establishes the requirements for each one (see Table 2).

\begin{tabular}{|l|l|}
\hline $\begin{array}{l}\text { Systems using signals transmitted } \\
\text { by low voltage wiring, such as } \\
\text { power line carrier systems. }\end{array}$ & $\begin{array}{l}\text { Nodes that inject signals from 3 kHz to 148.5 kHz into the low } \\
\text { voltage installation shall conform to the specifications in UNE-EN } \\
50065-1 \text { regarding electromagnetic compatibility. } \\
\text { For all other frequencies, they shall conform to harmonised standard } \\
\text { in force. }\end{array}$ \\
\hline $\begin{array}{l}\text { Systems using signals transmitted } \\
\text { by specific wiring for that } \\
\text { function, such as twisted pair, } \\
\text { parallel, coaxial, optical fiber. }\end{array}$ & $\begin{array}{l}\text { Without affecting the requirements that manufacturers of nodes, } \\
\text { actuators or input devices establish for the installation, when the } \\
\text { circuit transmitting a signal elapses for the same channel as another } \\
\text { low voltage, the insulation level of the wires and of the adjacent low } \\
\text { voltage wire will be equal, by using a single or several isolating } \\
\text { systems. }\end{array}$ \\
$\begin{array}{l}\text { Coaxial cables and twisted pairs used in the installation of cables } \\
\text { shall have characteristics equivalent to the standards of series EN } \\
\text { 61.196 and CEI -2 60 189. }\end{array}$ \\
$\begin{array}{l}\text { Systems using radiated signals, } \\
\text { such as infrared waves, radio } \\
\text { frequency, ultrasonic, or systems } \\
\text { connected to } \\
\text { telecommunications network. }\end{array}$ & $\begin{array}{l}\text { Additionally, issuers of systems using radio frequency signals or } \\
\text { telecommunication signals shall meet applicable national legislation } \\
\text { of "National Table of Frequency Allocation Regulation of } \\
\text { Telecommunications". }\end{array}$ \\
\hline
\end{tabular}

Table 2: Types of automation systems, table prepared from the contents of the technical instruction ITC-BT-51

Nevertheless, this regulation states that a home automation system can combine several of the above types. For example, there are four types of network topologies: ring, tree, bus and linear. But all these types could be found in the same smart building.

With regard to the general requirements of the facility, this instruction serves to emphasise the compliance of electromagnetic compatibility, and the importance of including all references, instructions and conditions for product installation in the project or technical report. It also notes that when the automation system is powered with very low voltage, the project must meet another one of the instructions included in *the REBT, entitled the 'ITC-BT-36' instruction. For all other cases, the requirements that apply to ordinary stresses are applicable.

Regarding the RICT, the inclusion of this legislation in the study is determined by the literature. The vast majority of published books, which theoretically address the regulation of domotics, cite this regulation as a reference standard. However, this 
legislation has not, until now, defined or characterised smart home installations. The main objectives of this legislation are:

- To ensure the right of all citizens to access the different telecommunication services by providing buildings with a suitable infrastructure, that is, the equipment necessary to make possible such access.

- To ensure the same right to all operators to have access to that infrastructure.

Therefore, it seems that the RICT does not apply specifically to home automation installations; it, however, does apply to the possible connection of these installations within the public telecommunications networks. Figure 1 shows how the RICT proposes these connections. This normative concept is known as 'digital home'. [24] However, it is important to note that this law regulates aspects of forecasting and wiring spaces not only in the common areas of the building, but also inside homes. This is very important, because these facilities are not only orientated to solve the connection with external networks but also play an important role as a base network for any type of housing management or automation.

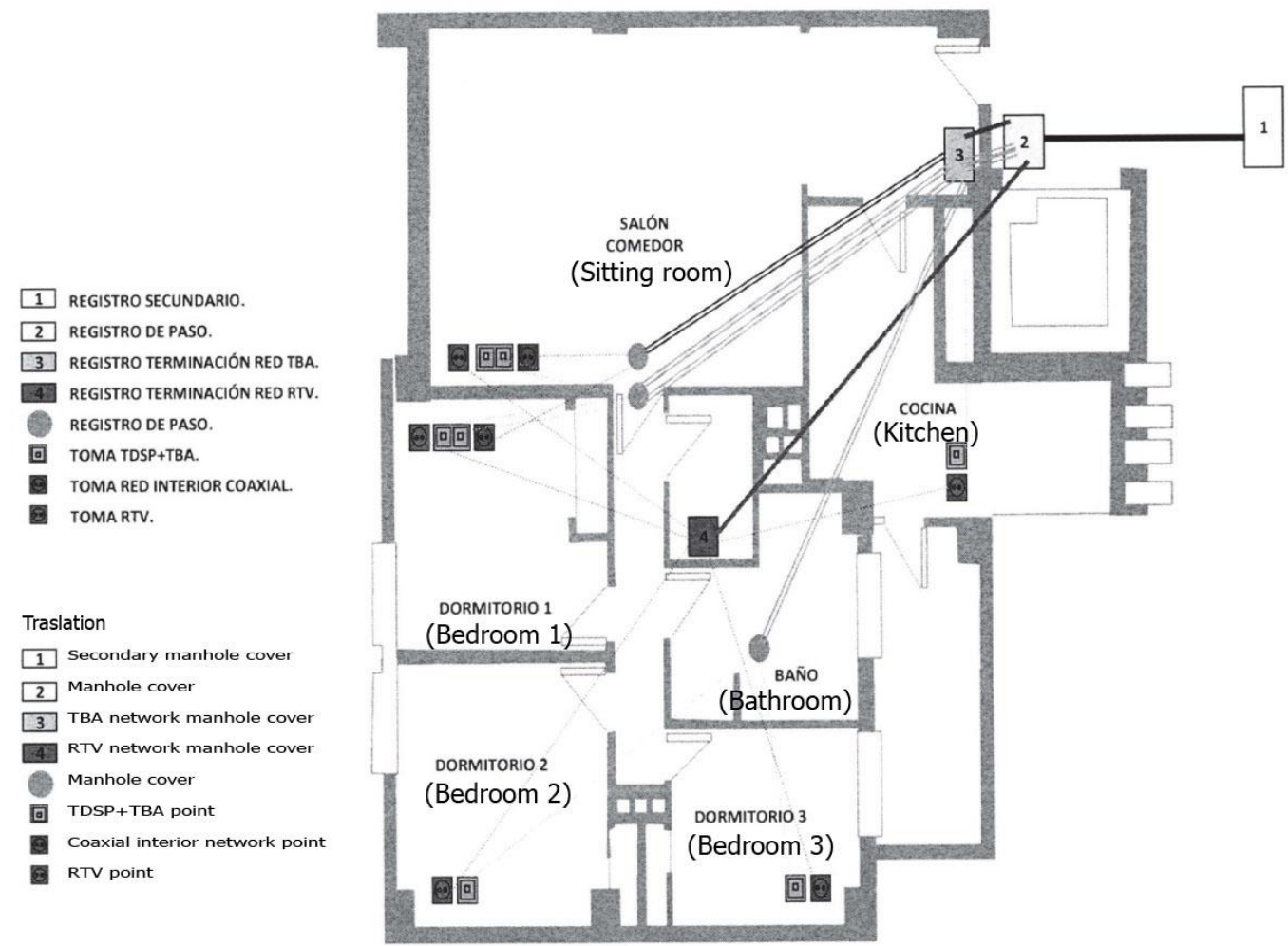

Figure 1: Adhering to the ICT Regulation, General Scheme of the Internal User Network

Additionally, a regulatory document coexists in Spain which is not legally binding which develops requirements for the design of smart buildings. This is the Technical Guide for the application of REBT, namely the paragraph 'GUIA-BT-51' [25]. It should also be noted that this guide proposes to conduct a pre-installation based on recommendations for the installation of these kinds of systems.

The regulatory documents which have been cited so far are state-owned. They are the only regulations that mention the term 'domotics' and are, therefore, the only ones that contain 'regulatory requirements that directly affect the design of smart buildings'. However, as has been observed in the 'variables' section of this study, it should be clarified that if the system interacts with the gas facility or with the energy saving system, then it must meet the rules relating to these areas of the building. For example: 
- 'Código Técnico de la Edificación (CTE)'. The 'documento básico HE' (requirements of energy saving) came into force on 29 September 2006. Its objectives are the rational use of energy and the promotion of renewable energy. It also sets the basic requirements of the quality of buildings and facilities.

- In the event that the home automation system interacts with the gas facility, it must meet the 'Regulations RD 919/2006', of 28 July, approving the technical regulation of distribution and use of gaseous fuels and technical instructions 'ICG 01-11'.

- If the security system is connected to a remote alarm, it needs to ensure compliance with 'RD 2364/1994', which approves the regulation of private security, and 'RD 1123/2001', by partially amending this regulation.

The requirements of these additional regulations not only indirectly affect the design of smart buildings, but they can have a significant impact on the outcome of the architectural project. For example, in Spain, the CTE came into force in 2006. This brought about the need to install photovoltaic solar panels in a series of buildings that met certain characteristics. The social purpose of this measure was to promote the use of renewable energy; and it has been achieved. The installation of solar panels in Spain increased significantly between 2005 and 2008 [26]. However, another consequence of this legislation, despite its support for alternative solutions, is that it does not stimulate research into alternative ways of producing electricity and, consequently, does not encourage technological advances in this direction.

Nevertheless, according to the statements of the Ministry of Housing of Spain, modifications that are being promoted in state legislation are aimed at achieving general requirements without explicitly forcing any technological solution. With this change in the law, the technological evolution of any constructional solution would not be compromised.

\section{6 - England and Wales: Regulation}

In England and Wales, all building regulations are included in the so-called 'Approved Documents' [27], and the latest update is the inclusion in 2006 of directives related to energy saving and electrical safety. Therefore, in the case of England and Wales, there is no legislation dedicated exclusively to the field of automation and smart buildings. For that reason, it is important to analyse all applicable state regulations to see if any of these affects the design of smart buildings.

By pursuing an exhaustive search of all approved British documents it can be shown that there are no 'Regulatory Requirements that directly affect the design of smart buildings'. This indicates that the law in the UK affects the design of smart buildings only indirectly. In the same way, it can be stated that there are no regulatory developments that deal specifically with 'Home and Building Electronic Systems'. For example, the 'Approved Document L1A' has references to control systems for energy saving purposes (Section 3, page 7), while 'Approved Document P' only addresses specifications for electrical installations in buildings. Even the 'IEE (IET) wiring regulations (BS 7671)', which are accepted as a way of fulfilling the legal requirements included inside Approved Document P, (although the IEE Wiring Regulations are nonstatutory), contain rules governing special installations or locations, but they only cover solar photovoltaic power supply systems or floor and ceiling heating systems.

British legislation is focused on objectives, meaning that the design must meet a final legal objective - although the legislation does not require a specific technical solution. This system is nowadays often cited by European Governments which support regulatory systems that promote technological evolution and freedom in the field of 
design. Meanwhile, Spanish legislation still builds its regulatory documents on regulatory requirements and, although this contradicts that freedom of design in construction solutions, it favours the development of new regulatory documents. With regard to cabling, while in Spain this matter is regulated in the RICT, the European reference standard are the documents 'EN 50173 (Performance requirements of generic cabling schemes)' and 'EN 50174 (Installation planning and practices inside buildings' both developed by CEN / CENELEC. In England and Wales the versions of application of these documents are the 'BS EN 50173' and 'BS EN 50174' but 'BS 6701' also applies (Telecommunications equipment and telecommunications cabling-Specification for installation, operation and maintenance) [28].

It is noteworthy that, thus far, the possibility to install or to provide a specific power line which will feed the devices and systems of a smart building has not been raised in any regulatory document.

Until a few years ago, most of the appliances and lighting systems in a home were fed directly from the electrical system of a house. However, a large proportion of electricity consumption devices in the modern home is connected via adaptors for 5 or 12 VDC (computers, mobile phones, systems based on LED lighting etc.)

Therefore, it seems appropriate to consider the desirability of DC power lines in housing. Existing homes are supplied with electrical power at $22 \mathrm{VAC}$ in Europe and 120 VAC in North America, whereas many devices, including small switchgear associated with smart buildings, require between 5 and 24 VDC.

\section{7 - Results and Market Data}

The most direct results come from the comparison between British and Spanish regulations and between these and European rules. As can be seen in Figure 2, both the Spanish and the British ordinances derive from the 'European Eurocodes'. However, Spanish law has now developed more documents outside of the Eurocodes. This documentation is composed of complementary regulations included in the following documents: the CTE, the documents of the 'RICT' and the 'REBT'. These last two documents are the only ones that contain 'regulatory requirements that affect the design of smart buildings'.
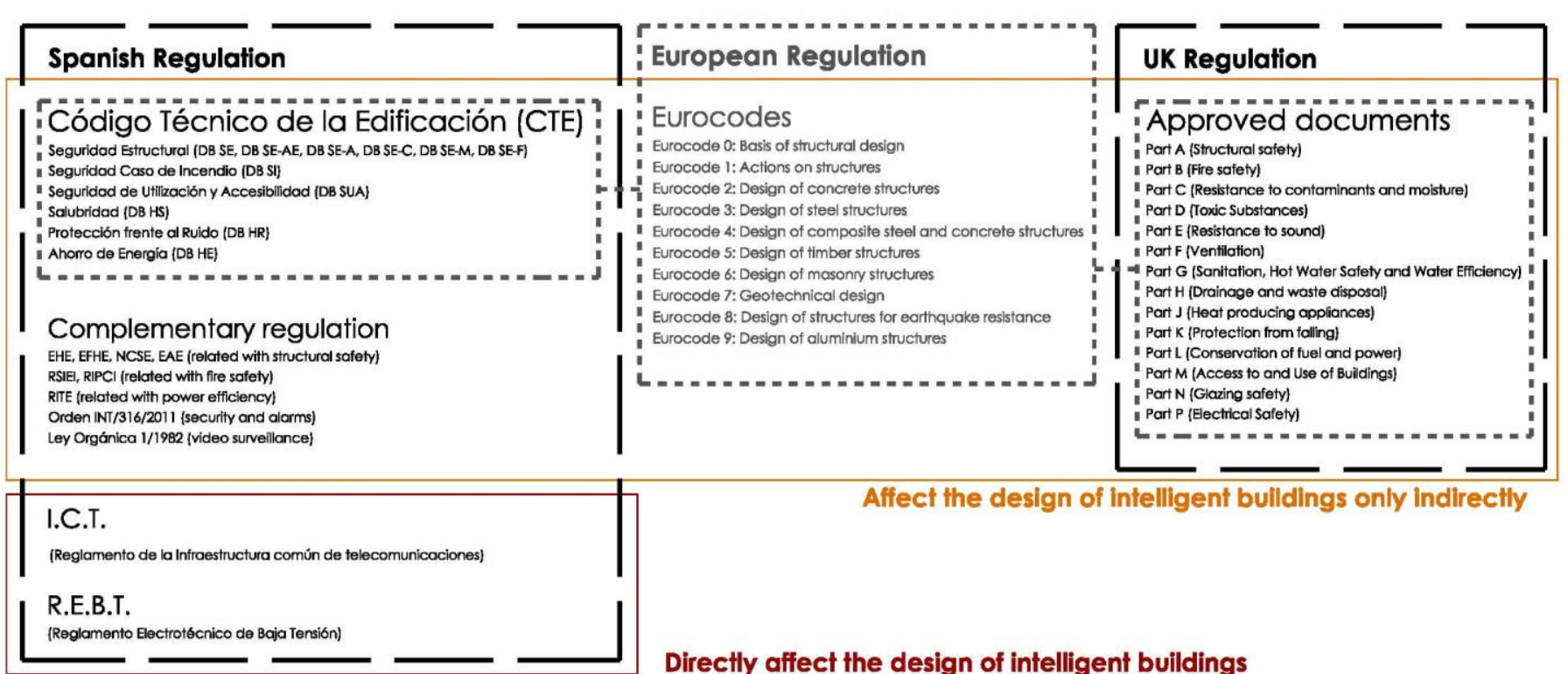

Affect the design of intelligent buildings only indirectly

Figure 2: Comparison of EU, Spanish and British legislation 
The main European associations for standardisation are 'CEN', 'CENELEC' and 'ETSI'. The international associations are 'ISO', 'IEC' and 'ITU', and the Spanish bodies are 'AENOR', 'Cerdá Institute', 'CEDOM', 'IDA' or 'ASIMELEC', which are developing non-mandatory regulations and guidelines to propose other ways to standardise and define the degree of automation in a smart building project. There is nothing similar in the UK, and therefore it is more difficult to find reliable information regarding market data and the inclusion of new technologies in the construction of buildings.

According to 'CEDOM' [29], economic and housing recession came to Spain just at a time when the building industry could rely, for the first time, on a regulatory and legislative framework that predicted good growth prospects between the years 2006 and 2007. This legislative framework took shape with the publication of the instruction 'ITC-BT-51' that emphasises the "specific requirements of the facility automation systems, energy management and technical security for homes and buildings, also known as 'automated systems' and later the 'AENOR' Specification EA0026, pioneered in Europe, which determines the minimum requirements to be met by an automated system.

The first market study in Spain, 'Project MercaHome' developed by the 'Institut Cerdà', 'CEDOM' and 'Casadomo.com' with 2004 data [30], concluded that the degree of penetration of home automation in new construction was about $7 \%$ and that $85 \%$ of home automation systems were installed in new buildings.

Subsequently, the 'CASADOMO MINT STUDIO' (2008) on home automation and security systems in new housing development was made, promoted and edited by casadomo.com and 'Simafutura construible.es', with the collaboration of 'ASPRIMA', 'CEDOM' and the guild of the leading brands [31]. This study, using data from 2007, placed the penetration of home automation in new developments at around $8 \%$.

The 'MercaHome' study expected $25 \%$ of home automation to be installed in new constructions in 2010, but the real estate crisis prevented this progression in Spain. Still, despite the $62 \%$ drop in new home construction, the percentage of home automation implementation has remained stable at $8 \%$. Nevertheless, it reveals that in the same year that the main changes in regulation were made (2007), the penetration of home automation increased by $1 \%$. If the same comparison be made with data from the 'Instituto nacional de Estadística' [32], the result is very similar (see Figures 3 and 4)

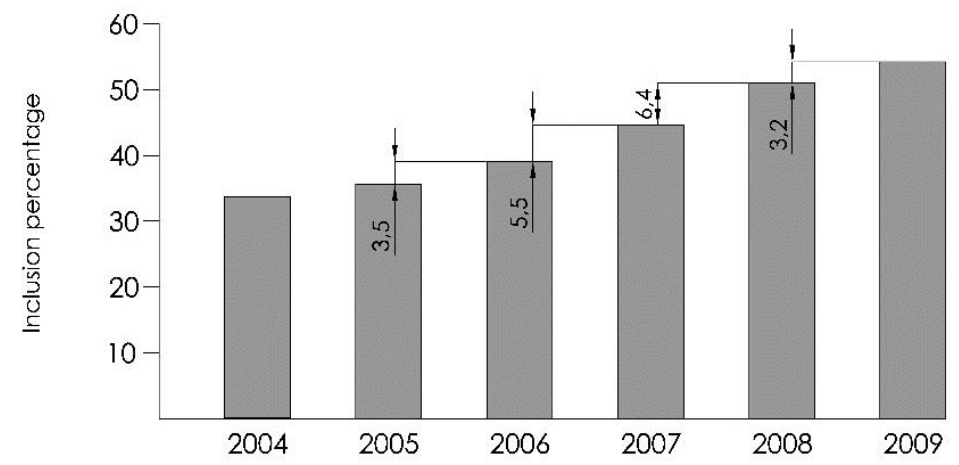

Figure 3: Percentage of households with Equipment and Use of Information Technologies and Communication 


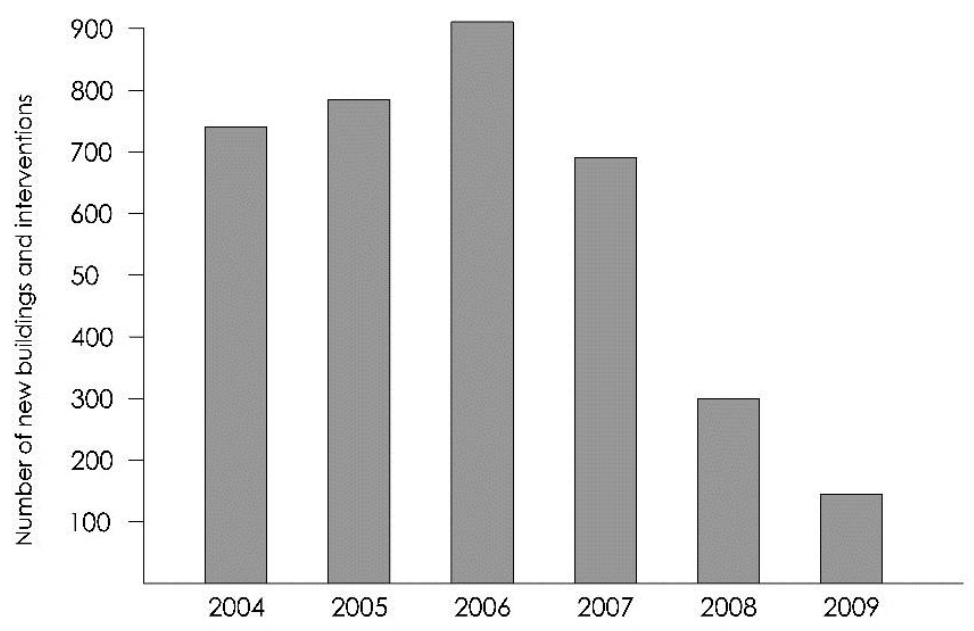

Figure 4: Number of new buildings and refurbishing interventions in dwelling in Spain

The current 'CEDOM' also believes that there is a combination of circumstances that can provide a boost to the development of the sector:

- 'The Directive 2010/31/EU' on energy efficiency of buildings promotes the installation of control systems in homes and buildings.

- 'The Action Plan E4' for 2011-2020, which includes new contents related to home automation and energy certification of buildings, promotes building technologies in the near future as advances to help save energy.

- The new 'RICT', which includes a Digital Home Annex, promotes widespread implementation and development of technologies in the home, by providing it with safety, accessibility, energy efficiency, comfort, communications and access to the services of an information society.

Due to the state of the market for new construction, the new build housing sector is redirecting its activities towards refurbishment and renovation. In 2010, the percentage of new developments with home automation had fallen to $64 \%$ compared with $85 \%$ six years ago. $46 \%$ of the home automation currently being installed in the residential sector is aimed at refurbishment and renovation.

In Britain, there are fewer home automation associations than in Spain, which means there is less information available regarding the penetration of home automation in construction. There are, however, other sources of information, such as the 'Construction Index' $[33,34]$. According to these sources, the private sector and new housing have borne the brunt of the recession, due in part to the focus on the construction required for the 2012 Olympic events._In any case, it seems that the economic crisis affects the volume of new buildings, but does not significantly alter the percentage of integrated home automation in new constructions.

Essentially, in both countries, it has been observed that the economic situation does not affect the introduction of new technologies in homes (see Table 3). Furthermore, the content of British legislation has not changed substantially over the last years while the Spanish one has included several regulatory documents about smart buildings, a fact that has had a considerable impact on the introduction of new technologies in the home. 


\begin{tabular}{|c|c|c|}
\hline Comparable data & Building regulation in UK & Building regulation in Spain \\
\hline $\begin{array}{l}\text { Regulation } \\
\text { philosophy }\end{array}$ & Regulation based on objectives & $\begin{array}{l}\text { Regulations based on specific } \\
\text { requirements }\end{array}$ \\
\hline $\begin{array}{l}\text { Specific } \\
\text { regulations in the } \\
\text { field of smart } \\
\text { buildings }\end{array}$ & None & $\begin{array}{l}\text { RICT and REBT contain captions } \\
\text { governing automation systems in } \\
\text { buildings }\end{array}$ \\
\hline $\begin{array}{l}\text { Existence of } \\
\text { regulatory } \\
\text { requirements that } \\
\text { directly affect the } \\
\text { design of smart } \\
\text { buildings }\end{array}$ & None & $\begin{array}{l}\text { Requirements that directly affect the } \\
\text { design of smart buildings have been } \\
\text { detected }\end{array}$ \\
\hline $\begin{array}{l}\text { Existence of } \\
\text { regulatory } \\
\text { requirements that } \\
\text { indirectly affect the } \\
\text { design of smart } \\
\text { buildings }\end{array}$ & $\begin{array}{l}\text { Requirements that indirectly } \\
\text { affect the design of smart } \\
\text { buildings have been detected }\end{array}$ & $\begin{array}{l}\text { Requirements that indirectly affect the } \\
\text { design of smart buildings have been } \\
\text { detected }\end{array}$ \\
\hline $\begin{array}{l}\text { Significant } \\
\text { regulatory changes }\end{array}$ & $\begin{array}{l}\text { inclusion in } 2006 \text { of directives } \\
\text { related to energy saving and } \\
\text { electrical safety }\end{array}$ & New RICT and REBT in 2006-2007 \\
\hline $\begin{array}{l}\text { Influence of } \\
\text { regulatory changes }\end{array}$ & $\begin{array}{l}\text { There are insufficient data to } \\
\text { establish a direct link but neither } \\
\text { has been registered a significant } \\
\text { change in the penetration rate of } \\
\text { smart buildings }\end{array}$ & $\begin{array}{l}\text { Public and private sources indicate an } \\
\text { increase in the penetration rate of smart } \\
\text { buildings coincident with the adoption } \\
\text { of new regulatory documents }\end{array}$ \\
\hline $\begin{array}{l}\text { Influence of the } \\
\text { economic situation } \\
\text { in the smart } \\
\text { buildings market }\end{array}$ & $\begin{array}{l}\text { It does not significantly alter the } \\
\text { percentage of integrated home } \\
\text { automation in new constructions }\end{array}$ & $\begin{array}{l}\text { It does not significantly alter the } \\
\text { percentage of integrated home } \\
\text { automation in new constructions }\end{array}$ \\
\hline
\end{tabular}

Table 3: Main differences between British and Spanish regulations

\section{8- Conclusions}

The first and most important conclusion of this research is that requirements can directly or indirectly affect the design of smart buildings. These requirements can be found and catalogued inside the official documents of each country and represent the influence of specific building regulations in smart buildings.

The available market data and statistical findings have been analysed as indicators to assess the impact of this regulation applicable to Smart Buildings. In this regard, it has been concluded that in Spain the regulatory improvements promoted in 2007 helped to increase the penetration of home automation in new developments, and, what is more, despite the recession this percentage has been stable.

There are also the following secondary conclusions from this research:

'Regulatory requirements that directly affect the design of smart buildings' and 'Regulatory requirements that indirectly affect the design of smart buildings' exist within legislative documents, both of which influence the introduction of new technologies in building projects.

However, the development of building regulations in each country is not the same, and their revision can influence the penetration of home automation in new construction. For example, new requirements may be included to stimulate the diffusion of automation and energy saving systems. Updating the British building regulation in this way would be recommended, in order to encourage the implementation of automated systems.

Finally, taking into account the analysis of statistical data and market data, the 
economic situation does not appear to affect directly the rate of penetration of home automation in construction. It is, therefore, important to note that the inclusion of domotics would appear to depend more directly on the technical requirements of the regulation than on the global economic situation. 'Domotics' may become a means of complying with the rules and not an end in itself.

\section{9 - References}

[1] Dewsbury, G and Edge, H. (2000). Designing the home to Meet the Needs of Tomorrow...Today: Deconstructing and rebuilding the home for life. ENHR2OO Conference June 2000, Gavle 26-30.

[2] García-S Matachana, E., \& Lopez Peñalver, F. J. (2004). El estado del arte de la tecnología al servicio de la construcción. Informes de la Construcción, 56(494), 1926.

[3] Bach, B., Wilhelmer, D., \& Palensky, P. (2010, July). Smart buildings, smart cities and governing innovation in the new millennium. In Industrial Informatics (INDIN), 2010 8th IEEE International Conference on (pp. 8-14). IEEE.

[4] Edge, M., Taylor, B., Dewsbury, G., \& Groves, M. (2000). The potential for 'smart home'systems in meeting the care needs of older persons and people with disabilities. Seniors Housing Update, 10(1), 6-8.

[5] Thistle, M. B. (2013). Smart buildings save energy and money [Microsoft in Government] From: http://www.microsoft.com/government/ww\%2Fpublicservices \%2Fblog/Pages/post.aspx?postID=301\&aID $=4$.

[6] Hsieh, H. F., \& Shannon, S. E. (2005). Three approaches to qualitative content analysis. Qualitative health research, 15(9), 1277-1288.

[7] Lee, D. H., Ryu, S. J., Cho, D. W., \& Kim, D. J. (1996). A comparative study of Korean and Japanese industrial policies through content analysis of official documents. Hitotsubashi Journal of Commerce and Management, 31, 59-74.

[8] Tilt, C. A. (2001). The content and disclosure of Australian corporate environmental policies. Accounting, Auditing \& Accountability Journal, 14(2), 190-212.

[9] Palmquist, M. (1980). Content analysis. from https://www.ischool.utexas.edu/ palmquis/courses/content.html.

[10] Elo, S. and H. Kyngäs (2008). The qualitative content analysis process. Journal of advanced nursing 62(1): 107-115.

[11] Romero, C., Vázquez, F., \& De Castro, C. (2006). Domótica e Inmótica. Viviendas y edificios inteligentes. $R A-M A, 2^{a} \mathrm{ed}$. Del.

[12] Escuela Universitaria de Ingeniería Técnica Industrial de Zaragoza. (2012). Autómatas en la Historia. From: http://automata.cps.unizar.es/Historia/Webs/automatas_en_la historia.htm.

[13] de Honnecourt, V. (2001). Cuaderno de dibujos (Vol. 9). Ediciones AKAL.

[14] Domínguez, H. M., \& Vacas, F. S. (2006). Domótica: Un enfoque sociotécnico. Fundación Rogelio Segovia para el Desarrollo de las Telecomunicaciones.

[15] Wong, J. K. W., Li, H., \& Wang, S. W. (2005). Intelligent building research: a review. Automation in Construction, 14(1), 143-159.

[16] Moya, J. M. H., \& Tejedor, R. J. M. (2004). Domótica: edificios inteligentes. Creaciones copyright.

[17] Flórez de la Colina, M. A. (2004). Hacia una definición de la domótica. Informes de la Construcción, 56(494), 11-17.

[18] Finch, E., \& Clements-Croome, D. (1997). University courses in intelligent buildings-new learning approaches. Facilities, 15(7/8), 171-176. 
[19] Ministerio de Vivienda. (2006). Código Técnico de la Edificación. From: http://www.codigotecnico.org/web/recursos/documentos/.

[20] Millán Anglés, S., et al. (2010). Research and analysis about determining constructive and project factors in domotic housing, Design, Technology and Management of Buildings, 37th IAHS World Congress on Housing Cience.

Santander (Spain).

[21] Ministerio de Fomento. (2006). Historia del Código Técnico de la Edificación. From: http://www.codigotecnico.org/web/cte/historia/.

[22] Ministerio de Industria, E. y. T. (2011). Normativa de las infraestructuras Comunes de Telecomunicaciones, (I.C.T.). Orden ITC/1644/2011 de 10 de junio.

From: https://www.boe.es/diario_boe/txt.php?id=BOE-A-2011-10457.

[23] Ministerio de Industria, E. y. T. (2008). Reglamento de Baja Tensión, (R.E.B.T.) Real Decreto 1890/2008, ed. Liteam ediciones.

[24] Junestrand, S., Passaret, X., \& Vázquez, D. (2004). Domótica y hogar digital. Editorial Paraninfo.

[25] Ministerio de Industria, E. y. T. (2007). Guía técnica de aplicación del R.E.B.T.: reglamento electrotécnico para baja tensión. Real Decreto 842-2002. Editorial Paraninfo.

[26] El Pais.com. (2006). Líderes mundiales en captación solar. From: http://elpais.com/diario/2006/04/02/negocio/1143983010_850215.html

[27] UK Government. (2012). Approved Documents. From: http://www.planningportal.gov.uk/buildingregulations/approveddocuments/

[28] Gilmore, M., \& Manivannan, M. (2012). Telecommunications Cabling: Guidance on standards and best practice for construction projects. BSI Standards Limited.

[29] CEDOM. (2012). Estudio CEDOM 2011, TENDENCIAS DEL MERCADO ESPAÑOL DE DOMÓTICA E INMÓTICA. From: http://www.cedom.es/fitxers/documents/publicacions/CEDOM_Estudio\%20Tenden cias\%20Mercado\%202011.pdf

[30] CASADOMO. (2004). El proyecto MERCAHOME. From: http://www.casadomo.com/noticias/-7295

[31] CASADOMO. (2008). Estudio MINT-CASADOMO 2008. From: http://www.casadomo.com/articulos/estudio-mint-casadomo-2008

[32] Instituto Nacional de Estadísitica (2014). Encuesta sobre Equipamiento y Uso de Tecnologías de la Información y Comunicación en los hogares. from $\mathrm{http}: / / \mathrm{www}$. ine.es $/ \mathrm{jaxi} / \mathrm{menu}$. do?type $=$ pcaxis\&path $=\% 2 \mathrm{Ft} 25 \% 2 \mathrm{Fp} 450 \&$ file $=$ inebase $\& \mathrm{~L}=0$.

[33] The Construction Index. (2010). Regional Construction Forecast Data 2010:

The Big Picture. From: http://www.theconstructionindex.co.uk/marketdata/regional-construction-forecast-data/2010/the-big-picture

[34] Statistics, U. N. (2014). Gateway to UK National Statistics. from http://www.statistics.gov.uk/hub/search/index.html?newquery=dwelling.1. Lee, D.-H., et al., A comparative study of Korean and Japanese industrial policies through content analysis of official documents. Hitotsubashi journal of commerce and management, 1996. 31: p. 59-74. 